\title{
THE ECONOMIC AND SOCIAL DILEMMAS OF MANAGEMENT FOCUSED ON THE FUTURE OF RETAIL BRANCHES OF COMMERCIAL BANKS IN POLAND
}

doi: 10.2478/cqpi-2019-0005

Date of submission of the article to the Editor: 29/04/2019

Date of acceptance of the article by the Editor: 30/05/2019

Leszek Wanat ${ }^{1}$ - orcid id: 0000-0002-1166-9258

Sylwia Klus ${ }^{2}$ - orcid id: 0000-0003-2477-8610

Elżbieta Mikołajczak ${ }^{2}$ - orcid id: 0000-0001-9416-4361

${ }^{1}$ Collegium Da Vinci in Poznań, Faculty of Social Sciences, Poland

2Poznań University of Life Sciences, Faculty of Economics and Social Sciences, Poland

\begin{abstract}
The problem of leadership and human resource management in commercial banks is a challenge to the growing dominance of e-commerce businesses. Scientific discussions are invariably focused on pro-competitive activities, however, the economic efficiency of which is not always sufficient. In this paper the authors attempt to identify economic and social factors leading to the future and development of retail branches of commercial banks in Poland. The research was carried out by the means of a diagnostic survey in retail branches of selected commercial banks.
\end{abstract}

Keywords: retail bank branch, bank manager, user experience, manager experience, Poland.

\section{INTRODUCTION}

Dynamic changes have been identified on the Polish retail banking market. They concern both technological and regulatory aspects (legal status), and, above all, strong competition in the industry. This situation requires from the financial sector organization an accurate analysis of the occurring phenomena and an adequate, quick response. A leading role in this area is played by retail branch managers organizing work of banking advisors and having direct contact with bank clients.

In this perspective, there is a permanent discussion on the future of bank branches, and then a new role of managers and customer service employees. This discussion concerns both cognitive and scientific perspectives, as well as utilitarian one, directly connected with the application of new solutions in management practice. The technological revolution and the systematic implementation of innovative IT solutions give rise to speculations about the imminent end of traditional banking branches. Contemporary bank clients are constantly expecting from financial institutions a wide application of technological novelties in order to improve services and their availability. Simultaneously, however, the same clients do not want to completely give 
up the expertise and help from the advisor, which can be obtained personally in the real bank branch (Brańka, 2017). Even the bold hypotheses of economics and behavioral psychology do not assume the total dominance of automation and the participation of virtual advisors only, while eliminating the services of authentic interpersonal relations. Indeed, some banks have already changed the business model in their branches by marginalizing or completely eliminating cash services. These banks, such as Bank Handlowy in Warsaw S.A. (Citi Handlowy), are only advisory. Conversely, business models are sought, focusing on the full independence of clients in banking services, which is offered, for example, by the Getin Point service provided by Getin Bank. There is, therefore, a dispute between traditional marketing and relationship marketing in banking services, a conflict between automation and virtualization of services, and the need for personalization.

In such conditions, both owners and managers of retail banks have to react. It is necessary to take adequate actions to stand out in the highly competitive local banking market. These activities are expected to balance the convenience of new technologies with trust, sometimes being accustomed to traditional services, based on the advisor-client relations, respecting the perspective of individual user experience (Wanat and Kielar, 2009). It seems that the reference to the User Experience (UX) model can determine the trust of customers who, apart from high technology, will also be offered the highest quality of service. Only the analysis of the current competitive situation in the retail banking sector makes undertaking research in this area justified and necessary.

\section{AIM OF THE RESEARCH, MATERIAL AND METHODS}

A the aim of the paper was to identify conditions that influence the modern model of retail bank manager's work. The research was conducted on the example of selected retail branches of commercial banks in the Poznań agglomeration ${ }^{1}$.

On their basis, an attempt was made to assess key aspects of management, determining the market power of bank retail branches and their ability to build a competitive advantage. In the research carried out in 2014 and 2018, the diagnostic survey method was used. An original questionnaire was applied (Klus, 2014), and, at the same time, an analysis of a multiple case study. The hypothesis was verified, in which it was assumed that one of the main factors for the development of retail banking is the increase in the activity of bank managers through building relationships with clients and cooperation networks within their commercial banks.

In the first stage, the survey was conducted on a random sample of clients of retail banks (100 questionnaires). The survey technique and a direct in-depth interview were used. In the subjective scope of the study, clients of selected retail branches of 6 commercial banks with their registered offices in the Poznań agglomeration were

\footnotetext{
${ }^{1}$ In the spatial scope of the paper, referred to the contractual concept of the 'Poznan agglomeration', first defined by Paweł Swianiewicz and Urszula Klimska (Swianiewicz and Klimska, 2005), followed by Jerzy Jan Parysek (Parysek, 2008) and formulated in the documents of the Metropolia Poznań Association (Czyż, 2011) and in the Local Data Bank studies of The Central Statistical Office (Kaczmarek, 2017; Budner, 2018), municipal, urbanrural and rural communes were included: Poznań, Buk, Czerwonak, Dopiewo, Kleszczewo, Komorniki, Kostrzyn, Kórnik, Luboń, Mosina, Murowana Goślina, Pobiedziska, Puszczykowo, Rokietnica, Stęszew, Suchy Las, Swarzędz and Tarnowo Podgórne. The selection was applied independently of other studies and classifications using the term 'Poznan agglomeration'.
} 
included: PKO BP S.A., Pekao S.A., Crédit Agricole Bank Polska S.A., Citi Handlowy S.A., Santander Bank Polska S.A. (until 2018 BZ WBK S.A.) and Millennium S.A. The study identified the degree of banks' interest in the level of service quality provided to clients from the perspective of customers as consumers of banking services and their user experience (aggregated, mean UX index [lux]). For the descriptive analysis, updated [lux] indicators were adopted in 2018 and their percentage change compared to 2014 [ $\Delta$ lux]. It was found that only $41 \%$ [-2\% (2014)] of bank customers believe that their bank is interested and monitors the level of their clients' satisfaction. In addition, it has been shown that as many as $38 \%$ of clients [+ $3 \%$ (2014)] cannot assess the level of the bank interest in their experience (UX) as service consumers, and $25 \%$ [+ $3 \%(2014)]$ are convinced of the total lack of interest.

The obtained results were then referred to the factors identified in the second stage of research by bank branch managers. Based on the professional experience of bank managers (MX, Manager Experience, $\left.\left[I_{M X}\right]\right)$, it has been shown that one of the most important activities of pro-competitive banks is accurate identification of customer needs ( $83 \%$ of responses, including $\left[\Delta \mathrm{lux}_{\mathrm{u}}, 2014=0\right]$ ). The relationship of these two observations, referring to User Experience (UX) and Manager Experience (MX), and having a market character (combining the demand and supply aspects), provides additional justification for research on new business models of retail banking.

In the second stage of the research, an attempt was made to identify conditions that influence the modern model of retail bank manager's work. The study was conducted by means of a diagnostic survey in the group of bank branch managers, for whom the size of the research sample was determined by a targeted selection (Klus, 2014). Six out of 41 commercial banks operating on the Polish financial market in the year of the study commencement were selected for the research (2014). Due to this limitation, all branches of the surveyed banks in the Poznan agglomeration were included in the research conducted by means of the survey and direct in-depth interviews. Unfortunately, the bank PKO BP S.A. refused the permission to conduct research in its departments. Finally, 22 branches of banks were included in the study, out of 42 operating in the selected area.

The basic research tool was the original questionnaire (Klus, 2014). From the supply perspective (Manager Experience, MX), the following were identified: the main competitors on the market, economic and social factors of building a competitive advantage and business models that could be used by bank retail branches in the future (Costa et al., 2006; Gietl and Haufler, 2018). The evaluation of the importance of identified factors $\left[\mathrm{I}(\mathrm{n})_{\mathrm{MX}}\right]$ was made on a scale of 1 to 5 (from [1] 'does not affect' to [5] 'has a key effect' with intermediate values).

\section{RESEARCH RESULTS AND DISCUSSION}

The criteria proposed in the questionnaire did not constitute a closed list. The factors of competitiveness, determined at the same time as potential factors for the development of retail banks, were initially identified based on the current state of knowledge. The results of the research conducted by: Sikorski (1995), Dowgiałło and Zadworny (2005), Penc (2005), Vieira (2013), Kiełtyka (2016), Rogers (2016), Mbama et al. (2018) and Sayil et al. (2019) were applied in the study. The focus was on internal factors (intra-bank), giving the remaining factors in the adopted research scenario the status of ceteris paribus. 
The bank branch managers' responses were then collected, aggregated and summarized in Table 1.

Table 1

Identification of potential development factors [I(n)Mx] for banking retail branches according to the experience of managers (MX) of selected commercial banks in Poland ${ }^{2}$

\begin{tabular}{|c|c|c|c|c|c|c|c|}
\hline $\begin{array}{l}\text { Factors for development } \\
\text { of bank retail branches } \\
\text { in selected banks }\left[1(n)_{M x}\right]\end{array}$ & $\begin{array}{l}\text { PKO } \\
\text { B.P. } \\
\text { S.A. }\end{array}$ & $\begin{array}{l}\text { Pekao } \\
\text { S.A. }\end{array}$ & $\begin{array}{c}\text { Crédit } \\
\text { Agricole } \\
\text { Bank } \\
\text { Polska } \\
\text { S.A. }\end{array}$ & $\begin{array}{c}\text { Citi } \\
\text { Han- } \\
\text { dlowy } \\
\text { S.A. }\end{array}$ & $\begin{array}{l}\text { BZ } \\
\text { WBK } \\
\text { S.A. }\end{array}$ & $\begin{array}{l}\text { Mille- } \\
\text { nnium } \\
\text { S.A. }\end{array}$ & $\begin{array}{c}\text { Average } \\
\text { impact } \\
\text { value } \\
{\left[I(n)_{M x}\right]}\end{array}$ \\
\hline $\begin{array}{l}\text { Organizational structure of } \\
\text { the bank }\left[\mathrm{I}(1)_{\mathrm{Mx}}\right]\end{array}$ & 3,80 & 3,00 & 3,10 & 3,50 & 3,53 & 3,45 & 3,40 \\
\hline Size of the bank $\left[\mathrm{I}(2)_{\mathrm{Mx}}\right]$ & 4,60 & 4,06 & 3,00 & 3,00 & 3,91 & 3,27 & 3,64 \\
\hline $\begin{array}{l}\text { Identification of employees } \\
\text { with strategic goals of the } \\
\text { bank [I(3) } \mathrm{Mx}]\end{array}$ & 3,91 & 3,18 & 4,00 & 4,00 & 4,09 & 3,00 & 3,70 \\
\hline $\begin{array}{l}\text { Innovative service sales } \\
\text { models }\left[I(4)_{\mathrm{Mx}}\right]\end{array}$ & 3,91 & 4,06 & 3,20 & 5,00 & 4,16 & 3,64 & 4,00 \\
\hline $\begin{array}{l}\text { Efficiency of internal } \\
\text { communication systems } \\
{\left[1(5)_{M x}\right]}\end{array}$ & 4,18 & 3,59 & 3,30 & 5,00 & 3,74 & 3,55 & 3,89 \\
\hline $\begin{array}{l}\text { Level of independence in } \\
\text { making decisions }\left[\mathrm{l}(6)_{\mathrm{Mx}}\right]\end{array}$ & 3,36 & 3,56 & 3,00 & 4,00 & 3,69 & 3,20 & 3,47 \\
\hline $\begin{array}{l}\text { Bank personnel policy } \\
\text { (stabilisation) }\left[\mathrm{I}(7)_{\mathrm{Mx}}\right]\end{array}$ & 3,36 & 3,29 & 3,50 & 4,00 & 3,51 & 3,40 & 3,51 \\
\hline $\begin{array}{l}\text { Management culture } \\
\text { (atmosphere at work) } \\
{\left[1(8)_{\mathrm{Mx}}\right]}\end{array}$ & 4,18 & 3,94 & 4,30 & 5,00 & 4,39 & 4,27 & 4,35 \\
\hline Incentive schemes $\left[\mathrm{I}(9)_{\mathrm{Mx}}\right]$ & 4,09 & 3,53 & 4,30 & 5,00 & 4,07 & 4,36 & 4,22 \\
\hline Training systems [l(10)mx] & 3,91 & 3,59 & 3,90 & 4,50 & 3,84 & 3,73 & 3,91 \\
\hline $\begin{array}{l}\text { Employees' involvement } \\
\text { (relationship marketing) } \\
{\left[\mathrm{l}(11)_{\mathrm{MX}}\right]}\end{array}$ & 4,91 & 4,64 & 4,80 & 4,50 & 4,80 & 4,82 & 4,55 \\
\hline Employees' age [l(12) $\mathrm{Mx}]$ & 3,80 & 3,00 & 3,10 & 3,50 & 3,53 & 3,45 & 3,40 \\
\hline $\begin{array}{l}\text { Employees' gender } \\
{\left[\mathrm{I}(13)_{\mathrm{Mx}}\right]}\end{array}$ & 4,60 & 4,06 & 3,00 & 3,00 & 3,91 & 3,27 & 3,64 \\
\hline $\begin{array}{l}\text { Professional experience } \\
\text { (seniority) }\left[\mathrm{I}(14)_{\mathrm{Mx}}\right]\end{array}$ & 3,91 & 3,18 & 4,00 & 4,00 & 4,09 & 3,00 & 3,70 \\
\hline $\begin{array}{l}\text { Banking business model } \\
{\left[\mathrm{I}(15)_{\mathrm{MX}}\right]}\end{array}$ & 3,91 & 4,06 & 3,20 & 5,00 & 4,16 & 3,64 & 4,00 \\
\hline $\begin{array}{l}\text { Culture of mutual trust } \\
{\left[\mathrm{l}(16)_{\mathrm{MX}}\right]}\end{array}$ & 4,18 & 3,59 & 3,30 & 5,00 & 3,74 & 3,55 & 3,89 \\
\hline $\begin{array}{l}\text { Cooperation among bank } \\
\text { branches }\left[\mathrm{I}(17)_{\mathrm{Mx}}\right]\end{array}$ & 3,36 & 3,56 & 3,00 & 4,00 & 3,69 & 3,20 & 3,47 \\
\hline $\begin{array}{l}\text { Other intra-banking factors } \\
{\left[\mathrm{I}_{\left.(18)_{\mathrm{Mx}}\right]}\right.}\end{array}$ & 3,36 & 3,29 & 3,50 & 4,00 & 3,51 & 3,40 & 3,51 \\
\hline
\end{tabular}

Source: authors' original analysis based on surveys $(2014,2018)$ and (Klus, 2014)

Despite the potential opportunity to individualize responses, managers were very conservative and cautious about open questions, relatively rarely using this option. An

\footnotetext{
${ }^{2}$ Assessment of the importance of factors [I(n)mx] on a scale from 1 to 5 (from [1] 'does not affect' to [5] 'has a key effect' along with intermediate values) was made by bank managers.
} 
important question posed in the context of the tendency to centralize the management of banking services was the issue of the level of independence of decisions made by managers and employees of retail branches of commercial banks (Kotter, 2012). This level, along with the increase in the automation and virtualization of banking services, has gradually been limited.

The leadership model in a modern institution (Wanat and Potkański, 2010; Potkański et al., 2011), which a bank manager could and should accept, becomes vulnerable and marginalized to the level of a technocrat official. In this seemingly 'secure' business model, not only the role of the manager is subject to limitation, also the bank's client becomes more a petitioner than a business partner and an entity, a market participant.

The most important identified development factors which affect building a competitive advantage of retail branches of commercial banks include: culture of mutual trust, built between the bank and the client (average ratio 4.86); employee involvement, understood as participation in building relationship marketing (4.55) and management culture, reflecting the actual working atmosphere at the bank branch (4.35). In addition, factors with an impact of above 4 points. included: incentive system, related to the remuneration and rewarding of employees (4.22) and the bank's business model (4.10), closely related to innovative models of sales of services offered by the surveyed banks. Also noteworthy is the factor indicated in the open part of the questionnaire concerning cooperation between the bank's branches (4.08).

This may seem surprising, since until now strong internal competition between individual retail branches of a given commercial bank has been perceived as one of the barriers to development. The necessity to overcome this barrier, perceived by the bank branch managers themselves, should be considered as a signal of directional changes in the management culture, identified in the top three potential development factors of the surveyed banks (4.35).

For comparison, in the research carried out in 2014, the three most important factors included: involvement of bank employees (4.78), work atmosphere (4.27) and effectiveness of employee motivation systems (4.05). A significant role was also given to the factor, which basically constituted the resource's competitive potential of the bank, i.e. the size of the bank. It is worth noting that managers of the largest commercial banks attributed much greater importance to this factor (PKO BP SA (4.60), Pekao SA (4.06) and BZ WBK SA (3.91), than the leaders of other, smaller banks (Klus, 2014; Kieżel, 2016).

Therefore, a certain change should be pointed out that gives priority to building a culture of trust, bank-client relationships and a culture of management based on these foundations. Additional opinions expressed freely by the bank managers surveyed (MX) emphasized that the identified development factors are directly related to the quality of customer service and their satisfaction as a measure of the user's individual experience (UX) (Kieżel, 2016; Gietl and Haufler, 2018; Mbama et al., 2018; Sayil et al., 2019).

These factors show that even the prospective implementation of blockchain technology and the automation of retail banking services will leave room for individual non-anonymous services and relationships built by managers of bank retail branches with their clients. 


\section{CONCLUSIONS}

The following conclusions were made on the basis of the conducted research:

1) The most important development factors identified in the research, having an impact on building the competitive advantage of retail branches of commercial banks, are closely related to the elements of management engineering, among which leadership, trust and building lasting relationships and cooperation networks, so social aspects showing a relatively greater impact than strictly economic ones, are at the forefront.

2) The main factors for the development of retail banking include social management factors: a culture of mutual trust, built between the bank and the client; involvement of bank employees, as a measure of their participation in building relationship marketing and management culture, reflecting the atmosphere at the bank branch (Potkański et al., 2011; Wanat and Potkański, 2011; Sanda and Kuada, 2016; Tam and Oliveira, 2019).

3) Lower than social factors, but an equally important role was assigned to economic conditions of management of retail branches of commercial banks, including incentive schemes related to employee remuneration and rewarding, as well as accurate selection and flexibility of business models of commercial banks and innovative sales models of services offered by the surveyed banks already at the retail level, in direct relations with clients (Campanella et al., 2018; Chernikova et al., 2018).

4) In this context, the hypothesis adopted in the introduction, which assumes that one of the main factors for the development of retail banking is the increase in the activity of bank managers through building customer relationships and cooperation networks within their commercial banks, can be verified positively.

The controversial nature of the hypothesis verified in the paper seems to mitigate a relatively new look at the paradigm of competitiveness in economic sciences. The potential economic symbiosis in the financial sector depends not only on the state's policy, but also on intra-banking institutional conditions.

Stabilization of these factors may have an impact on building competitive advantages at the local level for retail branches of commercial banks. Indeed, due to the dominance of e-commerce services, it seems necessary to maintain a diversified offer of banking services. This can happen by providing new functionalities, balancing access to resources and profiling consultancy services, so as not to exclude customers who do not keep up with the 'progress' from the market.

As a result, by building a value chain in the financial services sector at the local level, it seems necessary to include the co-operation factor in building a new service offer based on relationship marketing (Potkański and Wanat, 2017; Mbama et al., 2018; Sayil et al., 2019). The offer constructed in such a way may determine the competitive ability of the enterprise to a greater extent than the efficiency of resource use and the 'classic' competitive potential (Wanat et al., 2018).

This process aims to redefine the concept of competitiveness through partnership, which, by building cooperation networks, can become an important link in management engineering, including the management of bank retail branches.

\section{REFERENCES}

Brańka, M., 2017, 50 Największych Banków w Polsce 2017: Oddział przyszłości, czyli jak wyznaczać nowe standardy obsługi klientów, Bank, 6. 
Budner, W., 2018, Suburbanizacja w obszarze metropolii Poznań. Biuletyn Stowarzyszenia Rzeczoznawców Majątkowych Województwa Wielkopolskiego, 49(1), 26-34.

Campanella, F., Derhy, A., Gangi, F., 2018, Knowledge management and value creation in the post-crisis banking system, Journal of Knowledge Management, 23(2), 263-278, https://doi.org/10.1108/JKM-11-2017-0506.

Chernikova, L. I., Egorova, E. N., Evstefeeva, S. A., Shcherbakov, S. S., 2018, Influence of macro-economic conditions on sustainability of banking system. Espacios, 39(1), 23.

Costa, B. A., Jakob, K., Porter, G. E., 2006, Mutual fund performance and changing market trends 1990-2001: does manager experience matter?, The Journal of Investing, 15(2), 79-86, DOI: https://doi.org/10.3905/joi.2006.635634.

Czyż, T., 2011, Conceptions of an urban agglomeration and a metropolitan area in Poland. Geographia Polonica, 84(2), 5-17, http://dx.doi.Org/10.7163/GPol.2011.2.1.

Dowgiałło Z., Zadworny W., 2005, Rola menedżera w zarządzaniu przedsiębiorstwem, Szczecin, Wydawnictwo Książek Znicz.

Gietl, D., Haufler, A., 2018, Bonus taxes and international competition for bank managers, European Economic Review, 110, 41-60, DOI: 10.1016/j.euroecorev.2018.08.004.

Kaczmarek, T., 2017, Dynamika i kierunki rozwoju suburbanizacji rezydencjalnej w aglomeracji poznańskiej. Acta Universitatis Lodziensis. Folia Geographica SocioOeconomica, 27(1), 81-98, http://dx.doi.org/10.18778/1508-1117.27.06.

Kiełtyka, L., 2016, Rola menedżera we współczesnych organizacjach, Przegląd Organizacji, 8.

Kieżel, M., 2016, Innowacje banków detalicznych - przejaw marketingu relacji czy orientacji na produkt?; Acta Scientiarum Polonorum. Oeconomia, 15(3), 27-34.

Klus, S., 2014, Budowanie przewagi konkurencyjnej przez oddziały banków w obszarze bankowości detalicznej (analiza wybranych oddziałów w aglomeracji poznańskiej), PhD Thesis, unpublished, Uniwersytet Ekonomiczny w Poznaniu, Poznań.

Kotter, J. P., 2012, Co właściwie robią przywódcy, [in:] O przywództwie, Warszawa, ICAN Sp. z o.o. Sp. k.

Malewska, K., 2014, Intuicyjny menedżer a wymogi funkcjonowania współczesnych organizacji, Przegląd Organizacji, 3.

Mbama, C. I., Ezepue, P. O., 2018, Digital banking, customer experience and bank financial performance: UK customers' perceptions. International Journal of Bank Marketing, 36(2), 230-255, https://doi.org/10.1108/JJBM-11-2016-0181.

Parysek, J.J., 2008, Aglomeracje miejskie w Polsce oraz problemy funkcjonowania i rozwoju. [w:] J. J. Parysek, A. Tölle (red.), Wybrane problemy rozwoju i rewitalizacji miast: aspekty poznawcze i praktyczne. Biuletyn IGS-EiGP UAM w Poznaniu. Seria Rozwój regionalny i Polityka Regionalna. Bogucki WN., 5, Poznań, 29-48.

Penc, J., 2005, Role i umiejętności menedżerskie. Sekrety sukcesu i kariery, Warszawa, Difin Sp. z o.o.

Potkański, T., Wanat, L., Chudobiecki, J., 2011, Leadership in Time of Crisis or Crisis of Leadership? Implications for Regional Development, Intercathedra, 27(4), 45-52.

Potkański, T., Wanat, L., 2017, Dylematy rozwoju miejskich obszarów funkcjonalnych $z$ perspektywy partnerstw międzysamorządowych, Studia Komitetu 
Przestrzennego Zagospodarowania Kraju PAN, 174, 235-245, DOI: $10.24425 / 118535$.

Rogers, J., 2016, Menedżer jako coach. Nowoczesny styl zarządzania, Gdańskie Wydawnictwo Psychologiczne Sp. z o.o.

Sanda, M. A., Kuada, J., 2016, Influencing dynamics of culture and employee factors on retail banks' performances in a developing country context. Management Research Review, 39(5), 599-628, https://doi.org/10.1108/MRR-04-2015-0078.

Sayil, E. M., Akyol, A., Golbasi Simsek, G., 2019, An integrative approach to relationship marketing, customer value, and customer outcomes in the retail banking industry: a customer-based perspective from Turkey. The Service Industries Journal, 39(5-6), 420-461, DOI: 10.1080/02642069.2018.1516755.

Sikorski, Cz., 1995, Profesjonalizm, Warszawa, PWN.

Swianiewicz, P., Klimska, U., 2005, Społeczne i polityczne zróżnicowanie aglomeracji w Polsce-waniliowe centrum, mozaika przedmieść. Prace i Studia Geograficzne, 35, 45-70.

Tam, C., Oliveira, T., 2019, Does culture influence m-banking use and individual performance?, Information \& Management, 56(3), 356-363, https://doi.org/10.1016/j.im.2018.07.009.

Vieira, W., 2013, Menedżer sprzedaży na miarę XXI wieku, Warszawa, Wolters Kluwer Polska Sp. z o.o.

Wanat, L., Kielar, S., 2009, Toksyczne opcje walutowe. Przegląd Leśniczy, 3, 7-9.

Wanat, L., Potkański, T., 2010, Effective leadership as one of the pillars of development of knowledge-based economy, Intercathedra, 26, 182-185.

Wanat, L., Potkański, T., 2011, Barriers for effective regional leadership in time of crisis, Intercathedra, 4(27), 75-79.

Wanat, L.; Potkański, T.; $\quad$ Chudobiecki, J.; $\quad$ Mikołajczak, E.; $\quad$ Mydlarz, K., $\quad 2018$, Intersectoral and Intermunicipal Cooperation as a Tool for Supporting Local Economic Development: Prospects for the Forest and Wood-Based Sector in Poland. Forests, 9(9), 531, https://doi.org/10.3390/f909053. 